\title{
Effect of cell permeability and dehydrogenase expression on octane activation by CYP153A6-based whole cell Escherichia coli catalysts
}

\author{
Bronwyn E. White ${ }^{1,3}$, Caryn J. Fenner ${ }^{1,3}$, Martha S. Smit ${ }^{2,3}$ and Susan T. L. Harrison ${ }^{1,3^{*}}$
}

\begin{abstract}
Background: The regeneration of cofactors and the supply of alkane substrate are key considerations for the biocatalytic activation of hydrocarbons by cytochrome P450s. This study focused on the biotransformation of n-octane to 1-octanol using resting Escherichia coli cells expressing the CYP153A6 operon, which includes the electron transport proteins ferredoxin and ferredoxin reductase. Glycerol dehydrogenase was co-expressed with the CYP153A6 operon to investigate the effects of boosting cofactor regeneration. In order to overcome the alkane supply bottleneck, various chemical and physical approaches to membrane permeabilisation were tested in strains with or without additional dehydrogenase expression.
\end{abstract}

Results: Dehydrogenase co-expression in whole cells did not improve product formation and reduced the stability of the system at high cell densities. Chemical permeabilisation resulted in initial hydroxylation rates that were up to two times higher than the whole cell system, but severely impacted biocatalyst stability. Mechanical cell breakage led to improved enzyme stability, but additional dehydrogenase expression was necessary to improve product formation. The best-performing system (in terms of final titres) consisted of mechanically ruptured cells expressing additional dehydrogenase. This system had an initial activity of $1.67 \pm 0.12 \mathrm{U} / \mathrm{g}_{\mathrm{DCW}}$ (32\% improvement on whole cells) and attained a product concentration of $34.8 \pm 1.6 \mathrm{mM}$ after $24 \mathrm{~h}$ ( $22 \%$ improvement on whole cells). Furthermore, the system was able to maintain activity when biotransformation was extended to $72 \mathrm{~h}$, resulting in a final product titre of $60.9 \pm 1.1 \mathrm{mM}$.

Conclusions: This study suggests that CYP153A6 in whole cells is limited by coupling efficiencies rather than cofactor supply. However, the most significant limitation in the current system is hydrocarbon transport, with substrate import being the main determinant of hydroxylation rates, and product export playing a key role in system stability.

Keywords: Alkane activation, Octane, CYP153A6, Whole cell biocatalysis, Transport, Membrane permeabilisation, Cofactor regeneration, Glycerol dehydrogenase

\section{Background}

In recent decades there has been renewed interest in the activation of alkanes to position these widely available but unreactive hydrocarbons as a potential feedstock for

\footnotetext{
*Correspondence: sue.harrison@uct.ac.za

${ }^{1}$ Centre for Bioprocess Engineering Research (CeBER), Department

of Chemical Engineering, University of Cape Town, Private Bag X3,

Rondebosch, Cape Town 7701, South Africa

Full list of author information is available at the end of the article
}

the creation of diverse platform chemicals $[1,2]$. Owing to the stable nature of these molecules, chemical activation requires the use of high temperatures or harsh oxidants. Current methods are prone to low regioselectivity and over-activation $[1,3,4]$. To this end, the use of enzymes as biocatalysts has been explored $[4,5]$. The enzymes of the cytochrome P450 family have attracted attention owing to their diverse substrate range and high efficiencies for regiospecific terminal oxidation $[2,6,7]$. 
However, there are still numerous obstacles to be overcome if biocatalytic alkane activation is to be feasible at an industrial scale, including the enzymes' low activities and multi-component nature, their demand for cofactors, low substrate solubility and high toxicity of substrates and products [8-10].

The supply of cofactors can be a limiting step in hydrocarbon biotransformation, even where in vivo systems are used to provide cellular machinery for endogenous cofactor regeneration $[3,8,11]$. The co-expression of a dehydrogenase alongside the biotransformation enzyme can boost the cell's capacity to regenerate cofactors [1114]. There is, however, a risk that the increased metabolic burden may impact negatively on cell physiology and functioning $[15,16]$.

Limitations in passive transport of hydrocarbon substrates from the organic phase to the enzyme may be a more significant obstacle, as this results in unfavourable ratios between substrate and product in the vicinity of the hydroxylase, leading to slow reaction kinetics and encouraging over-oxidation of product, as supported by Grant et al. [17]. The low solubility and diffusion of hydrocarbons in the aqueous culture medium presents a challenge, but the key bottleneck is transport of hydrocarbons across the cell membrane [17-19]. To overcome this limitation, the membrane can be permeabilised via chemical solubilisation [18, 19], genetic mutation of key lipoproteins [20], or the co-expression of cross-membrane transporter proteins alongside the biotransformation enzyme [18, 21-23]. These techniques for enhanced transport are able to boost activities of biotransformation enzymes, although they often have negative effects on cell physiology and enzyme stability [18, 20, 22].

This study investigated cofactor supply and passive cross-membrane transport of substrate and product, using octane as a model substrate. The system consisted of resting Escherichia coli whole cells expressing a heterologous cytochrome P450, CYP153A6, and its natural electron transport partners, ferredoxin reductase and ferredoxin. Additional glycerol dehydrogenase was expressed alongside the CYP153A6 in an attempt to overcome the cofactor bottleneck. In order to investigate the transport bottleneck, membrane permeabilisation was carried out, using either exposure to chemical additives (acetone, Triton X-100 or polymyxin B) or mechanical breakage of cells.

\section{Results and discussion}

\section{Effects of glycerol dehydrogenase over-expression} in whole cells

For the investigation of cofactor effects, whole cells expressing the CYP153A6 operon, including ferredoxin and ferredoxin reductase (abbreviated as CYP), were compared to whole cells expressing CYP as well as additional heterologous glycerol dehydrogenase (abbreviated as CYP + GLD). Experiments were performed for low and high cell density cultures. In low cell density cultures the dehydrogenase was expressed on pCDFDuet, while in high cell density cultures the dehydrogenase was expressed on pACYCDuet. CYP was expressed on $\mathrm{pET} 28 \mathrm{~b}+$, and CYP-only strains also carried the appropriate empty Duet vector. The systems converted n-octane into 1-octanol; some octyl acetate by-product was also observed when the pACYCDuet vector was present. Octyl acetate was not observed in whole cell systems expressing pCDFDuet instead of pACYCDuet. The octyl acetate is clearly an artefact of the expression system: pACYCDuet contains a chloramphenicol resistance marker, expressing chloramphenicol acetyltransferase (CAT), which attacks one of the hydroxyl groups present on the chloramphenicol molecule. CAT has been shown to acetylate perillyl alcohol resulting from the hydroxylation of limonene by a cytochrome P450 [24], so it is the likely agent in the acetylation of 1-octanol.

In order to catalyse hydroxylation reactions, the CYP153A6 system requires electrons, which it obtains from the reduced form of the cofactor nicotinamide adenine dinucleotide (NADH). The oxidised form of the cofactor $\left(\mathrm{NAD}^{+}\right)$must be regenerated or the reaction will quickly exhaust the available cofactor supply. One of the benefits of in vivo systems is that cellular metabolism provides cofactor regeneration $[8,9]$. However, spectrophotometric assays performed in the absence of substrate suggested that the system in this study oxidised cofactor as fast as the cells could reduce it (Additional file 1: Figure S1; Table 1). It was hypothesised that cofactor supply was a limiting factor in the biotransformation of octane, and that the bottleneck could be alleviated through the co-expression of additional heterologous glycerol dehydrogenase. This strategy of boosting dehydrogenase expression to improve turnovers has been applied successfully in other hydrocarbon systems; for example, in the co-expression of alcohol dehydrogenase with CYP105A1 for hydroxylation of abietic acid [25], glucose dehydrogenase with an aldehyde reductase

Table 1 Glycerol dehydrogenase activities in whole cells

\begin{tabular}{lcc}
\hline & $\begin{array}{l}\mathbf{4 8} \boldsymbol{h} \text { Incubation } \\
\text { without substrate }\end{array}$ & $\mathbf{4 8} \mathbf{h}$ Biotransformation \\
\hline CYP & $-0.01 \pm 0.02$ & $0.00 \pm 0.02$ \\
CYP + GLD & $1.81 \pm 0.87$ & $1.49 \pm 0.32$ \\
\hline
\end{tabular}

Units of activity are $\mu$ moles $\mathrm{NAD}^{+}$reduced per minute per $\mathrm{mL}$. The above assays were performed on samples from low cell density cultures. The values displayed represent averages over two biological replicates, with multiple time points sampled per replicate 
from Sporobolomyces salmonicolor for reduction of ethyl 4-chloro-3-oxobutanoate [14], glucose dehydrogenase with a $\mathrm{P} 450_{\mathrm{BM}-3}$ mutant for oxyfunctionalisation of $\alpha$-pinene [13], and glycerol dehydrogenase with P450cam for oxygenation of camphor [12]. In this study, systems co-expressing additional glycerol dehydrogenase were shown to be capable of producing cofactor in excess of the cell's non-biotransformation usage (Additional file 1: Figure S1; Table 1).

However in the CYP153A6 systems, when octane was added to whole-cell cultures co-expressing additional dehydrogenase, product titres did not improve relative to cells expressing only the CYP operon (Fig. 1a), even though higher dehydrogenase activity should have been making more cofactor available (Table 1). In low cell density cultures, strains with excess NADH turnover produced a comparable amount of 1-octanol to those with unboosted cofactor regeneration rates (Fig. 1a). Specific production per gram dry cell weight was also not substantially different over the $48 \mathrm{~h}$ period (Fig. 1c). While specific production rates in terms of mmol product per $\mu \mathrm{mol}$ active P450 were higher for cells containing extra GLD (Fig. 1b), this was more likely due to reduced expression of CYP153A6 (Table 2). Looking at the CYP strain, low cell density cultures had substantially more active P450 per unit cells than high cell density cultures (0.382 vs $\left.0.224 \mu \mathrm{mol}_{\mathrm{P} 450} / \mathrm{g}_{\mathrm{DCW}}\right)$, yet their production per unit cells over the first 10-12 h was slightly lower, suggesting that CYP153A6 concentration was not limiting in the CYP strains. A similar argument can be made for the CYP + GLD strains: the high cell density culture had a slightly higher specific P450 concentration than the low cell density cultures $\left(0.187 \mathrm{vs} 0.140 \mu \mathrm{mol}_{\mathrm{P} 450} / \mathrm{g}_{\mathrm{DCW}}\right)$, yet it did not show higher rates per cell over the first 10-12 h.

In high cell density cultures, both strains showed similar volumetric titres for the first $10 \mathrm{~h}$ of biotransformation,
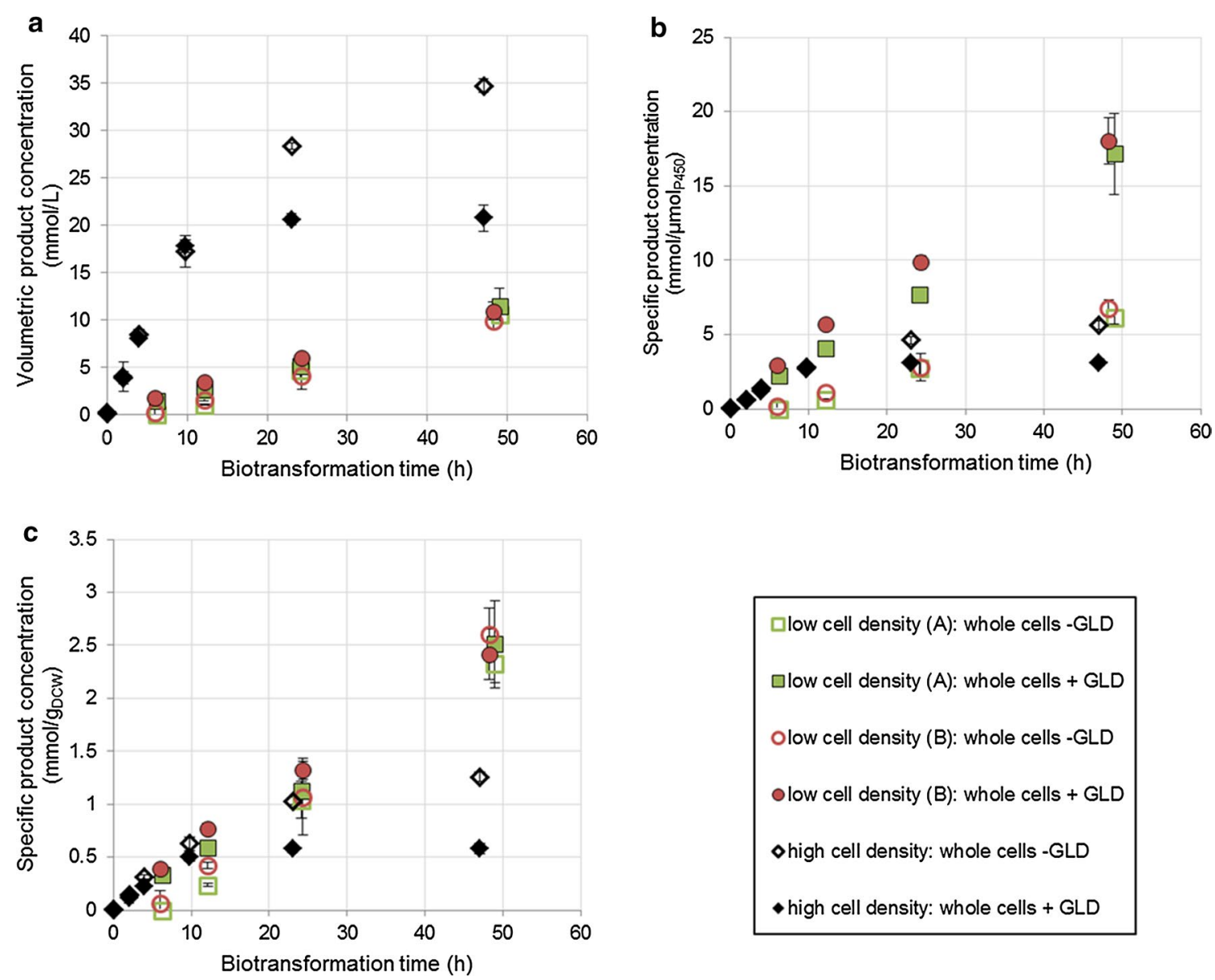

Fig. 1 Product formation in whole cells over $48 \mathrm{~h}$ of biotransformation. Low cell density was between 3.5 and $5 \mathrm{~g}$ Dcw/L. High cell density was $>25 \mathrm{~g}_{\mathrm{DCW}} / \mathrm{L}$. High cell density cultures produced octyl acetate by-product alongside 1-octanol (an artefact of the expression system). The product concentrations shown here are the combined concentrations of 1-octanol and octyl acetate. Two vials were sacrificed to obtain each sample point. The organic phase was extracted into ethyl acetate and analysed via gas chromatography 
Table 2 Average concentrations of active P450 over $24 \mathrm{~h}$ of biotransformation

\begin{tabular}{lll}
\hline Culture description & Volumetric concentration $(\boldsymbol{\mu M})$ & Specific concentration $\left(\boldsymbol{\mu m o l}_{\mathbf{p 4 5 0}} \mathbf{g}_{\mathbf{D} \mathbf{c w}}\right)$ \\
\hline Low cell density (A): whole cells -GLD & 1.72 & $0.380 \pm 0.013$ \\
Low cell density (A): whole cells +GLD & 0.67 & $0.146 \pm 0.005$ \\
Low cell density (B): whole cells -GLD & 1.47 & $0.384 \pm 0.018$ \\
Low cell density (B): whole cells +GLD & 0.61 & $0.134 \pm 0.006$ \\
High cell density: whole cells -GLD & $6.16 \pm 0.31$ & $0.224 \pm 0.013$ \\
High cell density: whole cells +GLD & $6.68 \pm 0.33$ & $0.187 \pm 0.014$ \\
Rupture -GLD & $4.93 \pm 0.25$ & $0.280 \pm 0.068$ \\
Rupture +GLD & $4.13 \pm 0.28$ & $0.238 \pm 0.018$ \\
Disintegration -GLD & $4.00 \pm 0.13$ & $0.247 \pm 0.025$ \\
Disintegration +GLD & $3.77 \pm 0.13$ & $0.240 \pm 0.008$ \\
Cell free extract -GLD & $3.91 \pm 0.21$ & $0.243 \pm 0.018^{\mathrm{a}}$ \\
Cell free extract +GLD & $3.52 \pm 0.13$ & $0.219 \pm 0.014^{\mathrm{a}}$ \\
Acetone +GLD & $5.40 \pm 0.27$ & $0.136 \pm 0.009$ \\
Polymyxin B +GLD & $5.98 \pm 0.49$ & $0.217 \pm 0.019$ \\
Triton X-100 +GLD & $5.14 \pm 0.20$ & $0.153 \pm 0.004$ \\
\hline
\end{tabular}

Measurements were taken at five time points over the first $24 \mathrm{~h}$ of biotransformation. Two vials were sacrificed at each time point for sampling. Concentration of active P450 was determined by CO difference spectrometry in a microwell spectrophotometer using $200 \mu \mathrm{L}$ (total) aqueous phase. The remaining aqueous phase was used to determine cell dry weight via pelleting and drying. In the case of cell free extract, specific values (marked ${ }^{\mathrm{a}}$ ) were calculated based on the cell dry weights of the homogenised culture from which the CFE was extracted

after which the productivity of the CYP + GLD strain fell off sharply (Fig. 1a). Again, this effect was also visible in the cell-based specific product concentration (Fig. 1c) and was slightly reduced in the P450-based specific product concentration owing to lower P450 expression in the CYP + GLD strain (Fig. 1b). Even in the high density CYP culture, cell-specific activity began lagging visibly after $10 \mathrm{~h}$. In contrast, low density cultures were still maintaining their initial activities after $48 \mathrm{~h}$ of biotransformation. This suggests a volumetric limitation, which is exacerbated by an excess of cofactor. Product toxicity would be the most obvious culprit, but since it was later found that mechanically permeabilised cells expressing additional GLD were able to maintain their activity relatively well at product concentrations exceeding those generated by whole cells (Fig. 2), it is clearly not the absolute volume of product that matters. Also, product toxicity cannot explain why whole cells expressing additional dehydrogenase matched the volumetric production of whole cells for the first $10 \mathrm{~h}$, but thereafter lost activity more rapidly. A more plausible explanation would be uncoupling of the hydroxylation reaction. Amongst the uncoupling reactions of $\mathrm{P} 450$ systems are the production of hydrogen peroxide $\left(\mathrm{H}_{2} \mathrm{O}_{2}\right)$ and the production of superoxide, which goes on to form $\mathrm{H}_{2} \mathrm{O}_{2}$ [26]. An excess of $\mathrm{H}_{2} \mathrm{O}_{2}$ is known to be detrimental to cellular functioning [27]. This could explain why the inhibition appears at high cell loadings (which correspond to higher volumetric enzyme concentrations) as well as why the presence of additional dehydrogenase causes the problem to worsen-the excess $\mathrm{NADH}$ is channelled into harmful uncoupling reactions instead of being used for hydroxylation of octane. This argument is further supported by the NADH turnovers in biotransforming cells, which are comparable to those in non-biotransforming cells (Table 1). In other words, the P450 enzyme was not limited by cofactor supply, at least in whole cells - rather, it was failing to access its preferred substrate, so it converted oxygen into superoxides or $\mathrm{H}_{2} \mathrm{O}_{2}$ instead.

\section{Effects of mechanical cell breakage}

Alkanes are sparingly soluble in water and do not easily pass through the cell membrane, and hence the supply of substrate has been identified as a major bottleneck in enzymatic hydrocarbon activation [27]. Some literature suggests that the key step is transfer of hydrocarbons across the outer membrane, and that altering the membrane structure to make it more permeable can improve hydroxylation of these substrates. Mutation of the Braun's lipoprotein to disrupt membrane rigidity improved toluene dioxygenase reaction rates by up to six times [20], while the expression of "channel" proteins allowing for passive diffusion of aromatics and terpenes increased product concentrations by up to five times [23]. To investigate the extent to which cross-membrane transport hindered the octane bioconversion, cells were homogenised at $15 \mathrm{kpsi}$ (enough to rupture the cell membranes) and $30 \mathrm{kpsi}$ (enough to disintegrate the cell membranes). 

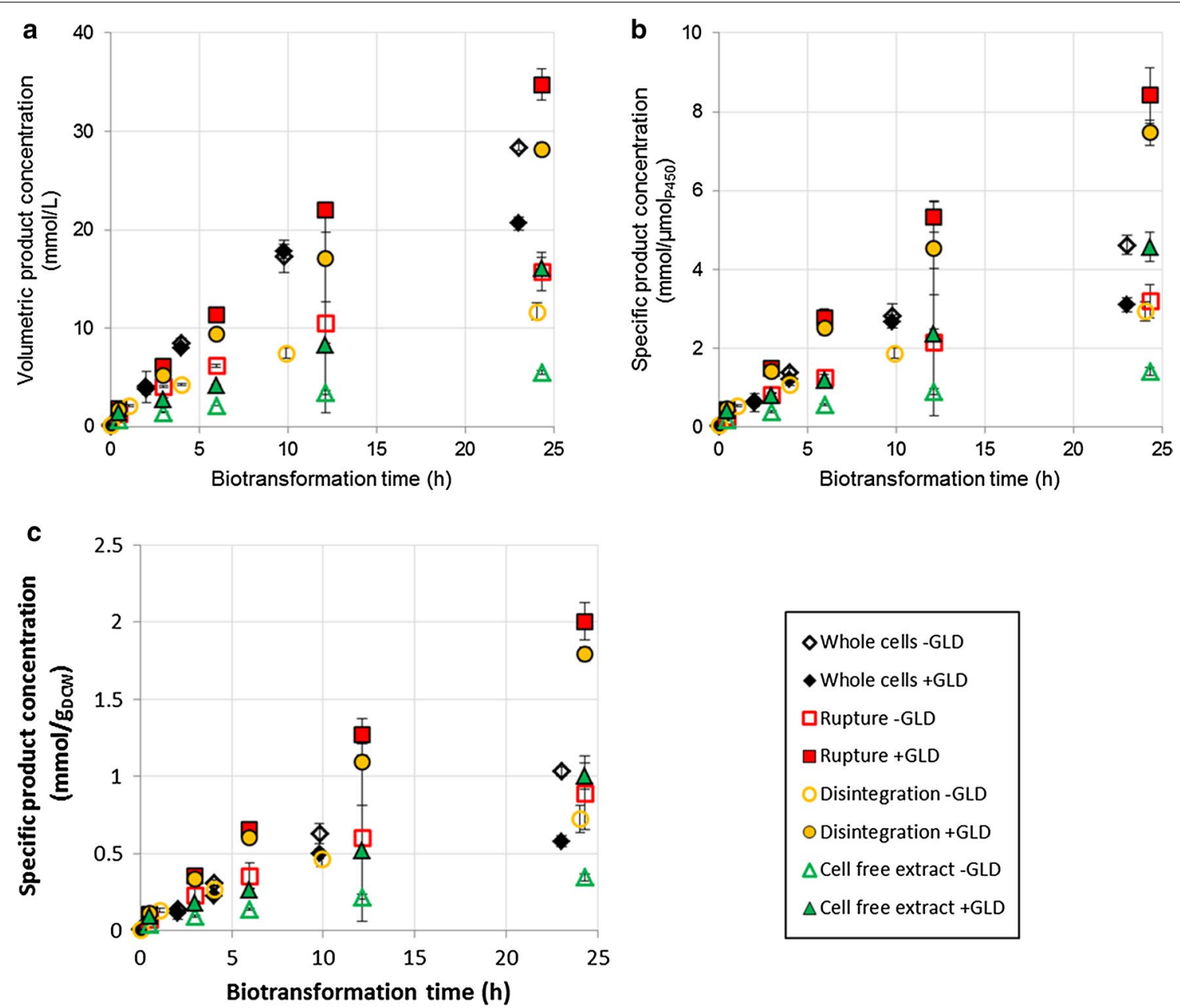

$$
\begin{aligned}
& \diamond \text { Whole cells -GLD } \\
& \diamond \text { Whole cells }+ \text { GLD } \\
& \square \text { Rupture -GLD } \\
& \square \text { Rupture +GLD } \\
& \text { Disintegration -GLD } \\
& \text { Disintegration +GLD } \\
& \triangle \text { Cell free extract -GLD } \\
& \Delta \text { Cell free extract +GLD }
\end{aligned}
$$

Fig. 2 Effect of additional GLD expression on product formation over $24 \mathrm{~h}$, using whole cells, mechanically broken cells or cell free extract. Cultures were at a high cell density, and produced octyl acetate by-product alongside 1-octanol (an artefact of the expression system). The product concentrations shown here are the combined concentrations of 1-octanol and octyl acetate. Two vials were sacrificed to obtain each sample point. The organic phase was extracted into ethyl acetate and analysed via gas chromatography

Treated cells were compared to whole cells and cell free extracts. High cell density cultures of cells carrying the pACYCDuet plasmid were used.

Over $24 \mathrm{~h}$, CYP + GLD strains where cells were ruptured or disintegrated managed to match or exceed the titres generated by whole cells (Fig. 2a) despite significantly lower volumetric P450 concentrations (Table 2). As a result, the permeabilised cells outperformed the whole cells in terms of specific productivities (Fig. 2b, c). Overcoming the transport limitation was essential for boosting effectiveness of the biocatalytic enzyme. This is in line with numerous other studies $[18,20,22$, $23,25,28,29]$. However, mechanically permeabilised cells that were not expressing additional GLD did not perform well relative to whole cells. Over a $24 \mathrm{~h}$ period they produced significantly lower volumetric titres, as well as demonstrating lower hydroxylation rates per unit enzyme and per unit cells. This suggests that some factor other than substrate transport was limiting in the CYP strains. The specific P450 concentrations of the permeabilised cells were higher than those that were previously argued to be non-limiting (Table 2), hence a lack of catalytic enzyme is unlikely to have been the cause. It is possible that the lack of an intact membrane resulted in cofactors "leaking out" and being distributed throughout the aqueous phase, meaning mechanically permeabilised cells had reduced access to cofactors. This would explain why only CYP + GLD strains exhibited improved production rates: the additional dehydrogenase expression was necessary to compensate for the dehydrogenase and cofactors lost due to permeabilisation. It could also explain why the CYP + GLD 
permeabilised cells did not experience the "poisoning" effect evident in CYP + GLD whole cells, where activity dropped off sharply after 10-12 h. Since permeabilised cells did not have an excess of cofactor, they did not experience excessive uncoupling and hence were not exposed to the same levels of $\mathrm{H}_{2} \mathrm{O}_{2}$.

It is unsurprising that cell free extract substantially underperformed relative to disintegrated cells and whole cells (with or without additional GLD expression), since cells are known to provide some benefit to enzyme functioning by maintaining a stable environment and ensuring proximity of interacting species [27]. However, the P450 in cell free extract retained its activity remarkably well (Table 3), such that CYP + GLD cell free extract was able to surpass the performance of CYP whole cells on a specific basis, when biotransformation time was extended (Additional file 2: Figure S2). However, productivity remained well below that of the ruptured or disintegrated cells.

It is worth noting that the best initial activity achieved by the CYP153A6 resting systems was $2.02 \pm 0.16 \mathrm{U} / \mathrm{g}_{\mathrm{DCW}}$ (disintegration $+\mathrm{GLD}$ ). This is well below the activities that $E$. coli have been shown to support. For example, Favre-Bulle et al. showed that growing $E$. coli expressing the alkane hydroxylase system of Pseudomonas oleovorans were able to hydroxylate n-octane at rates of up to $15 \mathrm{U} / \mathrm{g}_{\mathrm{DCW}}$ [30]. Resting E. coli can achieve similar rates-at low cell densities, Olaofe et al. observed hydroxylation rates of up to $16 \mathrm{U} / \mathrm{g}_{\mathrm{DCW}}$ 1-octanol for the CYP153A6 system [10]. If higher biocatalyst loading results in reduced specific activity, it suggests an as-yet unidentified physiological limitation.

\section{Chemical permeabilisation in the presence of additional} dehydrogenase

Aside from cell homogenisation, it is possible to permeabilise the membrane through the addition of certain chemicals. This study considered acetone, which increases membrane fluidity by disrupting lipid packing [31]; polymyxin B, an antibiotic peptide which partitions into the outer membrane and disrupts its structure [32]; and Triton X-100, a surfactant which has also been shown to disrupt E. coli outer membranes [33]. Since mechanically permeabilised cells had performed so poorly in the absence of additional dehydrogenase, chemical and mechanical permeabilisers were compared using CYP + GLD systems. However, the whole cell system included for comparison did not contain the additional dehydrogenase gene, given that CYP + GLD strains had underperformed when not permeabilised. High cell density cultures carrying the pACYCDuet plasmid were used.

The presence of Triton X-100 or polymyxin B had a positive effect on the initial hydroxylation rates (Fig. 3), which were higher than for any other system on both a volumetric and a specific basis. Initial volumetric rates were two to three times higher for these chemical permeabilisers than for whole cell CYP cultures (Table 3). However, after the first few hours of biotransformation the chemically permeabilised systems exhibited rapid activity loss, with minimal product formation after $10 \mathrm{~h}$, resulting in final titres up to $35 \%$ lower than those of whole cell CYP cultures and up to $65 \%$ lower than those of ruptured CYP + GLD cultures. As in other experiments, the same trends were present when considering production per unit enzyme, but the effects were dampened because

Table 3 Change in product formation rates over $24 \mathrm{~h}$ of biotransformation

\begin{tabular}{|c|c|c|c|}
\hline Culture description & Initial rate ${ }^{\mathrm{a}}\left(\mathrm{mmol} \mathrm{L}^{-1} \mathrm{~min}^{-1}\right)$ & Final rate ${ }^{b}\left(\mathrm{mmol} \mathrm{L}^{-1} \mathrm{~min}^{-1}\right)$ & Rate loss over $24 \mathrm{~h}(\%)$ \\
\hline Whole cells -GLD & $0.0348 \pm 0.0020$ & $0.0140 \pm 0.0017$ & 60 \\
\hline Whole cells +GLD & $0.0325 \pm 0.0010$ & $0.0036 \pm 0.0001$ & 89 \\
\hline Rupture -GLD & $0.0185 \pm 0.0001$ & $0.0071 \pm 0.0099$ & 62 \\
\hline Rupture +GLD & $0.0290 \pm 0.0003$ & $0.0175 \pm 0.0015$ & 40 \\
\hline Disintegration -GLD & $0.0131 \pm 0.0007$ & $0.0058 \pm 0.0006$ & 56 \\
\hline Disintegration +GLD & $0.0232 \pm 0.0013$ & $0.0151 \pm 0.0050$ & 35 \\
\hline Cell free extract -GLD & $0.0054 \pm 0.0003$ & $0.0028 \pm 0.0001$ & 48 \\
\hline Cell free extract +GLD & $0.0089 \pm 0.0009$ & $0.0106 \pm 0.0013$ & 0 \\
\hline Acetone +GLD & $0.0187 \pm 0.0010$ & $0.0084 \pm 0.0011$ & 55 \\
\hline Polymyxin B +GLD & $0.0626 \pm 0.0009$ & $0.0034 \pm 0.0016$ & 95 \\
\hline Triton X-100 +GLD & $0.1060 \pm 0.0015$ & $0.0002 \pm 0.0006$ & 100 \\
\hline
\end{tabular}

Measurements were taken at five time points over the first $24 \mathrm{~h}$ of biotransformation. Two vials were sacrificed at each time point for sampling. The organic phase was extracted into ethyl acetate and analysed via gas chromatography. Rates are based on the combined concentrations of 1-octanol and octyl acetate, which were the only significant products observed

a Calculated between 0 and $4 \mathrm{~h}$ of biotransformation

b Calculated between 10 and $24 \mathrm{~h}$ of biotransformation 

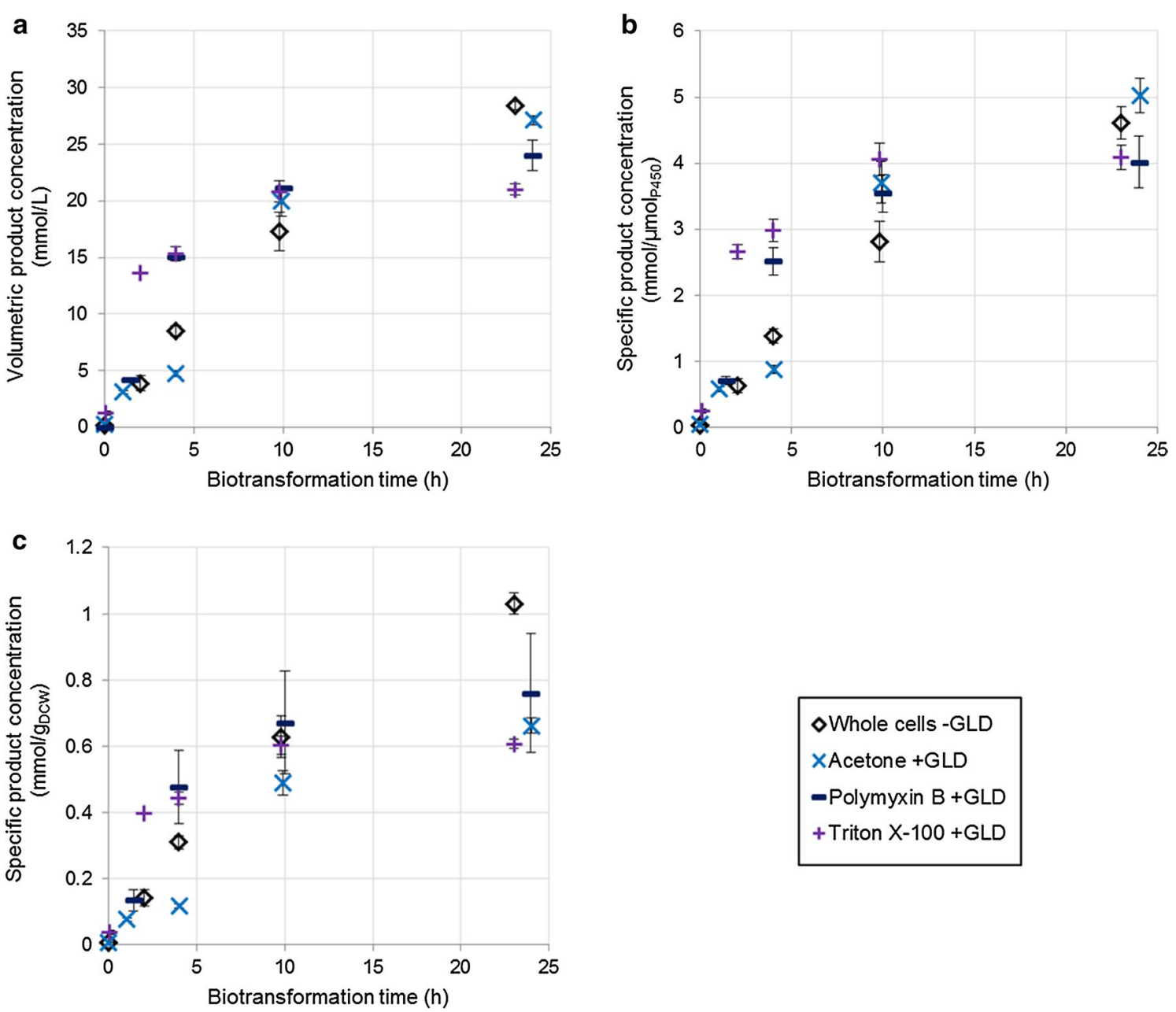

Fig. 3 Effect of additional GLD expression on product formation over $24 \mathrm{~h}$, using chemically permeabilised cells expressing additional GLD. Whole cells without additional GLD are included for comparison. Cultures were at a high cell density, and produced octyl acetate by-product alongside 1-octanol (an artefact of the expression system). The product concentrations shown here are the combined concentrations of 1-octanol and octyl acetate. Two vials were sacrificed to obtain each sample point. The organic phase was extracted into ethyl acetate and analysed via gas chromatography

of the reduced P450 concentration in the chemically permeabilised strains. These results are in agreement with authors such as Janocha and Bernhardt (2013) who found that polymyxin B could greatly enhance biotransformation rates, and that the effects were maximal when cofactor regeneration was boosted through heterologous expression. However, these authors used a limiting concentration of substrate and therefore did not investigate whether the high initial rates could be maintained. Considered over extended periods, the use of Triton X-100 has led to mixed results in the literature, with Grant et al. reporting a positive effect on the oxidation of dodecane in microwells and shake flasks when Triton X-100 was present [19], while Julsing et al. found that Triton X-100 was not helpful in the oxidation of fatty acid methyl esters
[18]. Bordeaux et al. found that Triton X-100 was moderately helpful in octane bioconversions when the organic phase included a co-solvent, but that the surfactant suppressed turnovers considerably when the organic phase consisted of pure octane [34]. Julsing et al. also used pure substrate as the organic phase, while Grant et al. had dimethylsulfoxide (DMSO) present in the organic phase, and found that the beneficial effects of Triton X-100 were enhanced when more DMSO was present. This suggests that the effectiveness of Triton X-100 is somehow linked to in situ product extraction. This study demonstrated a linear inverse correlation between initial hydroxylation rates and ability of $\mathrm{P} 450$ enzymes to maintain hydroxylation activity over $24 \mathrm{~h}$ of biotransformation (Fig. 4). The loss of activity was not linked to a loss of active P450, 


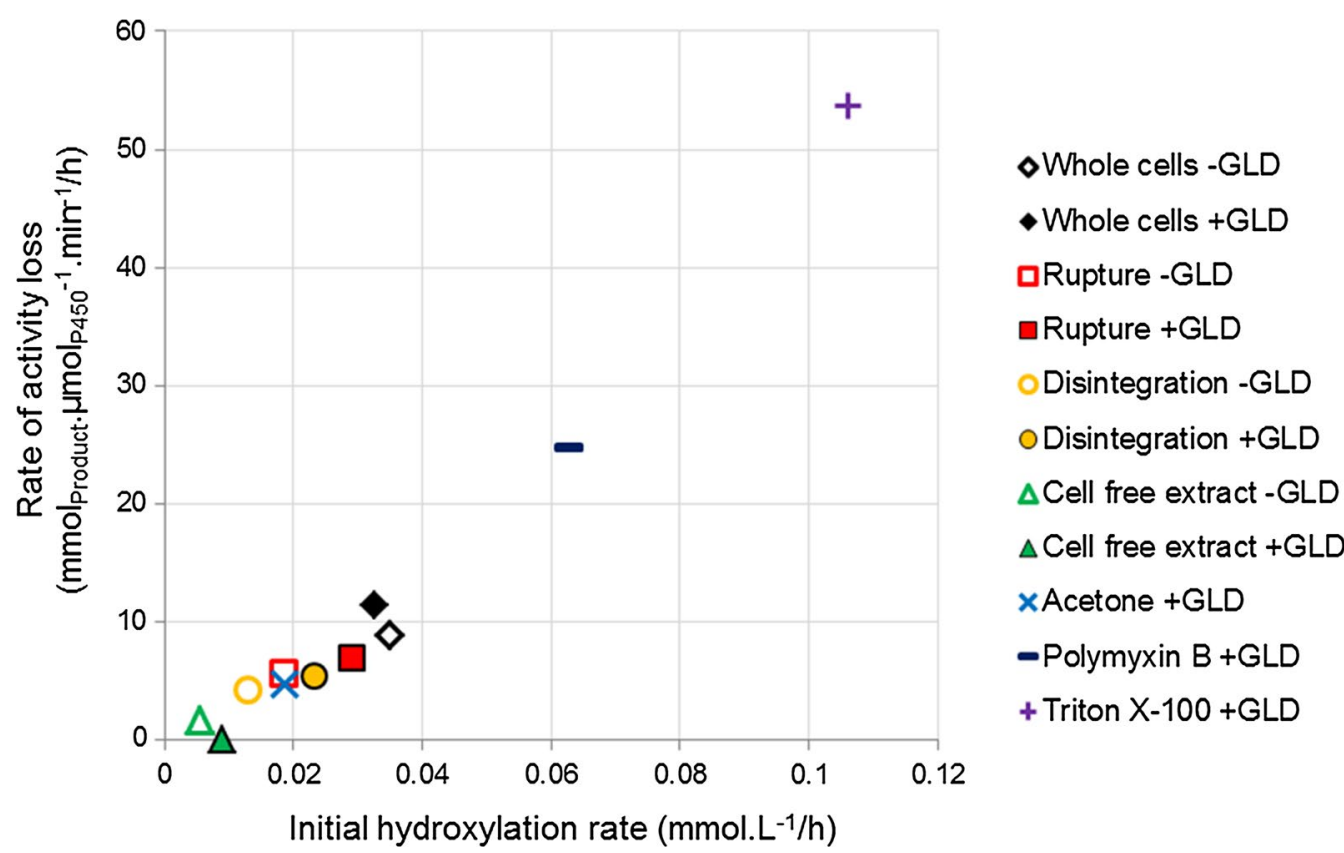

Fig. 4 Loss of P450 enzyme performance in various high cell density systems, as a function of initial hydroxylation rate. Values show a good linear correlation $\left(R^{2}=0.97\right)$

which did not decrease significantly over $24 \mathrm{~h}$ (Additional file 3: Figure S3). It also could not have been due to overall product concentration, since mechanically permeabilised cells expressing additional dehydrogenase had significantly higher final rates despite achieving higher final titres (Table 3; Figs. 2, 3). It is therefore hypothesised that it is the intracellular octanol concentration, rather than the volumetric product concentration, which results in negative toxicity effects. Systems permeabilised with polymyxin B or Triton X-100 produced 1-octanol more rapidly than it could be exported from the cell, leading to rapid intracellular build-up of toxic product which had a negative effect on cell physiology, hindering the bioconversion. Mechanically permeabilised cells, or cell free extract, where the product was produced less rapidly and could more easily move out of contact with cellular components, maintained their biocatalytic activities best (Table 3). This effect was not observed in ruptured or disintegrated cells that were not expressing additional dehydrogenase.

Acetone-treated cells performed poorly. Although they were able to reach the same titres as whole cell CYP cultures and performed comparably per unit enzyme (Fig. 3a, b), measurements of cell dry weight confirmed that cell density in the acetone experiment had been higher, while P450 concentration was slightly lower (Table 2). Per unit dry cell weight, acetone-treated cells showed lower initial rates than whole cells (Fig. 3c) with a comparable loss of activity over $24 \mathrm{~h}$ (Table 3), reducing the amount of product per cell by almost one-third.

\section{Passive transport in relation to by-product formation}

Although octyl acetate is an artefact of the pACYCDuet expression system, it provides an indication of how easily 1-octanol can exit the cell, since the extent of the acetylation reaction will be greater in cases where the 1-octanol produced by the P450 remains intracellular for longer periods. Grant et al. previously noted that changing phase ratios to improve substrate access and product extraction reduced overoxidation of dodecane in whole cell hydroxylation systems [19]. Comparing the concentration of 1-octanol and octyl acetate after $24 \mathrm{~h}$ of biotransformation, it can be seen that mechanically breaking the membrane greatly reduced the extent of by-product formation, as did treatment with polymyxin B (Fig. 5). The more compromised the membrane integrity, the lower the by-product formation. Triton X-100 did not have any significant effect relative to whole cells, possibly because it acts more as a hydrocarbon solubiliser than a membrane permeabiliser, and hence did not enhance product export to the same degree as substrate import. Acetone treatment was also ineffective at reducing by-product formation. Meanwhile, the expression of additional dehydrogenase in whole cells increased octyl acetate formation. Since this cannot be due to reduced product export relative to whole cells without GLD, it is 


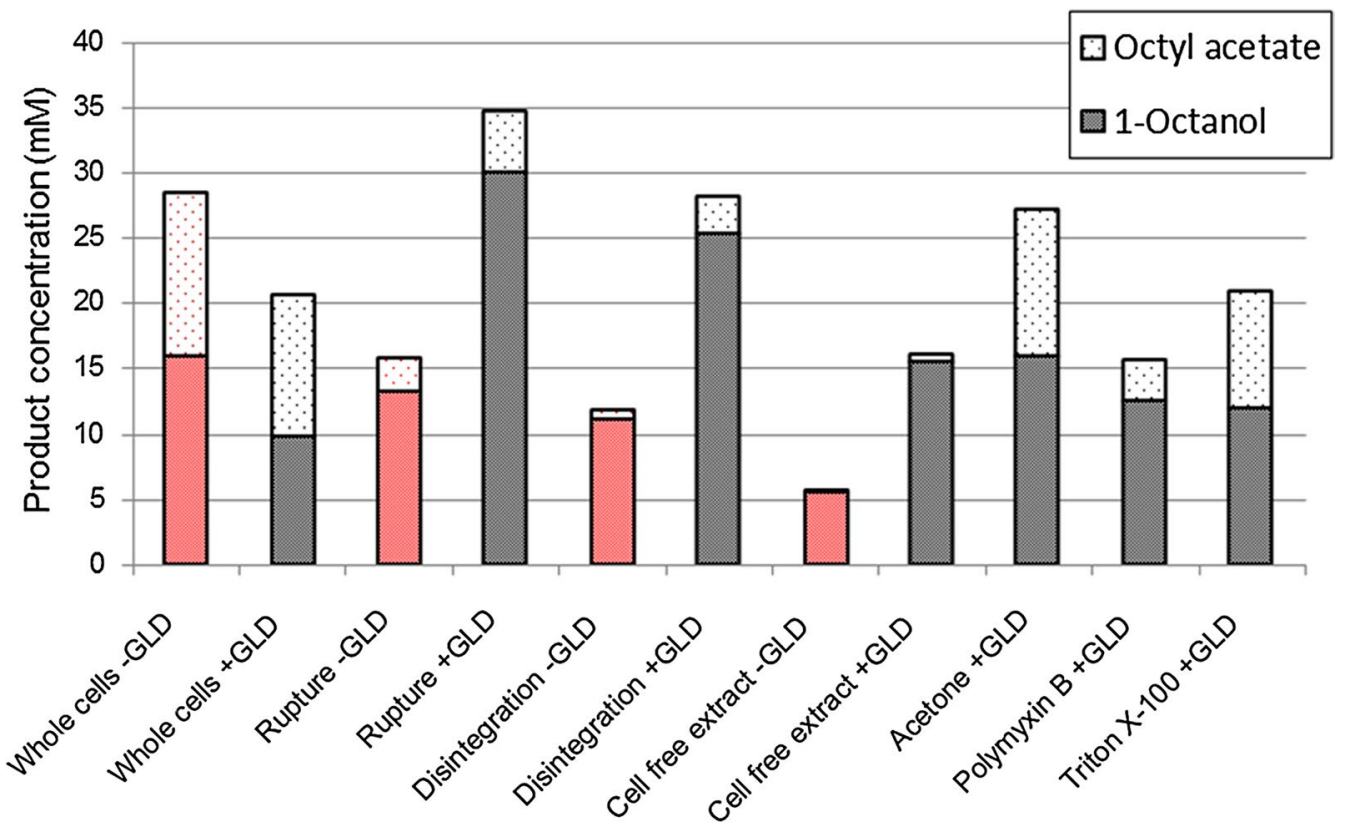

Fig. 5 Comparison of 1-octanol product and octyl acetate by-product formed in various high cell density systems over $24 \mathrm{~h}$ biotransformations. Two vials were sacrificed to obtain each sample point. The organic phase was extracted into ethyl acetate and analysed via gas chromatography

possible that this system had higher levels of CAT expression and hence higher acetylation activity.

\section{Conclusions}

The results of this study suggest that the cofactor requirements of CYP153A6 can typically be supplied by in vivo metabolic processes, and that boosting cofactor supply merely encourages harmful uncoupling reactions. The current system limitation is substrate supply; improving the passive transport into the cell through addition of Triton X-100 or polymyxin B led to significant improvements in initial rates of n-octane hydroxylation. However, product export is also an important factor, since the rapid accumulation of 1-octanol within the cell is cytotoxic. This led to cells being unable to maintain high hydroxylation rates for extended periods, and ultimately resulted in lower final titres for chemically permeabilised cells. Mechanically permeabilised cells, which presumably had improved product export, were able to maintain their initial hydroxylation activities for extended periods, allowing them to attain significantly higher production per cell. However, these mechanically permeabilised systems required the expression of additional dehydrogenase to compensate for cofactors lost during preparation. Further it requires an additional process unit operation, adding to process complexity. With this in mind, alternative permeabilisation techniques are worth considering. In recent years there has been much work done on membrane transporter proteins, with
Julsing et al. demonstrating the use of AlkL to enhance hydroxylation of fatty acid methyl esters [18], and Scheps et al. and Grant et al. subsequently demonstrating their usefulness in the hydroxylation of dodecanoic acid and C12-C16 alkanes [18, 22, 29]. It would be interesting to see how protein-based transport compares to chemical and mechanical enhancements in the CYP153A6 system, and whether such a system could gain any benefit from heterologous dehydrogenase expression.

\section{Methods}

Chemicals, bacterial strains and plasmids

Chemicals and antibiotics were obtained from SigmaAldrich and Merck. Escherichia coli BL21(DE3) was used as the host strain. Vectors used were pET28b $(+)$ containing the CYP153A6 operon from Mycobacterium sp. HXN-1500, pACYCDuet or pCDFDuet (without inserts) and pACYCDuet or pCDFDuet containing the $E$. coli glycerol dehydrogenase gene. All strains contained the CYP153A6 operon on pET28b+. Strains referred to as 'CYP' also carried one of the empty Duet vectors, while strains referred to as 'CYP + GLD' also carried one of the Duet vectors expressing glycerol dehydrogenase.

\section{Pre-cultures, medium preparation and expression of heterologous proteins}

Pre-cultures (5-10 mL) consisting of Luria-Bertani (LB) broth (10 $\mathrm{g} \mathrm{L}^{-1}$ tryptone, $5 \mathrm{~g} \mathrm{~L}^{-1}$ yeast extract, $5 \mathrm{~g} \mathrm{~L}^{-1}$ $\mathrm{NaCl}$ ) were inoculated from glycerol stocks (previously 
maintained below $-60{ }^{\circ} \mathrm{C}$ ). Pre-cultures were supplemented with $30 \mu \mathrm{g} \mathrm{mL} \mathrm{m}^{-1}$ kanamycin and either $30 \mu \mathrm{g} \mathrm{mL} \mathrm{m}^{-1}$ chloramphenicol (for strains containing pACYCDuet) or $100 \mu \mathrm{g} \mathrm{mL}^{-1}$ streptomycin (for strains containing pCDFDuet). Pre-cultures were then grown overnight $(\geq 12 \mathrm{~h})$ at $37^{\circ} \mathrm{C}$ with shaking.

Auto-induction (AI) medium was prepared from sterile solutions and had a final composition as follows: $9.2 \mathrm{~g} \mathrm{~L}^{-1}$ tryptone, $4.6 \mathrm{~g} \mathrm{~L}^{-1}$ yeast extract, $5 \mathrm{~g} \mathrm{~L}^{-1}$ glycerol, $0.5 \mathrm{~g} \mathrm{~L}^{-1}$ glucose, $2 \mathrm{~g} \mathrm{~L}^{-1} \alpha$-lactose for induction of heterologous expression, $3.3 \mathrm{~g} \mathrm{~L}^{-1}\left(\mathrm{NH}_{4}\right)_{2} \mathrm{SO}_{4}, 6.8 \mathrm{~g} \mathrm{~L}^{-1} \mathrm{KH}_{2} \mathrm{PO}_{4}$, $7.1 \mathrm{~g} \mathrm{~L}^{-1} \mathrm{Na}_{2} \mathrm{HPO}_{4}, 0.24 \mathrm{~g} \mathrm{~L}^{-1} \mathrm{MgSO}_{4}, 30 \mu \mathrm{g} \mathrm{mL}^{-1}$ kanamycin, $30 \mu \mathrm{g} \mathrm{mL}^{-1}$ chloramphenicol, $50 \mu \mathrm{M} \mathrm{FeCl}_{3} \cdot 6 \mathrm{H}_{2} \mathrm{O}$ (Saarchem) and $1 \mathrm{mM} \delta$-aminolevulinic acid.

Aliquots of AI medium were transferred to shake flasks (for a final working volume of $200 \mathrm{~mL}$ per $1 \mathrm{~L}$ flask volume). Cultures were inoculated at $2 \%(\mathrm{v} / \mathrm{v})$ and incubated at $20^{\circ} \mathrm{C}$ and $200 \mathrm{rpm}$ for $48 \mathrm{~h}$.

\section{Biocatalyst preparation Harvesting}

Following growth and enzyme expression, cells were centrifuged at $5000-7000 \mathrm{rpm}$ and $\leq 4{ }^{\circ} \mathrm{C}$ for $10 \mathrm{~min}$. The cell pellets were re-suspended in $200 \mathrm{mM}$ potassium phosphate buffer ( $\mathrm{pH}$ 8) containing $200 \mathrm{mM}$ glycerol. Low cell density cultures were resuspended to a concentration of $\pm 20 g_{\text {wet cell weight }} L^{-1}$. High cell density cultures were resuspended to a concentration of $\pm 0.4 \mathrm{~g}_{\text {wet cell weight }}$ $\mathrm{mL}^{-1}$, after which different portions of were subjected to a number of treatments designed to decrease the transportation barrier posed by the cell membrane.

\section{Whole cells}

A portion of high cell density culture was left untreated for use as a control; the cell suspension was diluted to a final concentration of $200 \mathrm{~g}_{\mathrm{WCW}} \mathrm{L}^{-1}$ using $200 \mathrm{mM}$ potassium phosphate buffer $(\mathrm{pH} 8)$ containing $200 \mathrm{mM}$ glycerol and $0.5 \mathrm{mM} \mathrm{NADH}$ (final concentration $0.25 \mathrm{mM})$.

\section{Mechanical cell breakage}

A portion of high cell density culture was homogenised using a one-shot cell disruptor (Constant Systems Ltd). Cells were homogenised at either 15,000 or $30,000 \mathrm{psi}$, and the resulting suspensions were diluted 1:1 with $200 \mathrm{mM}$ potassium phosphate buffer $(\mathrm{pH} 8)$ containing $200 \mathrm{mM}$ glycerol and $0.5 \mathrm{mM}$ NADH (final concentration $0.25 \mathrm{mM}$ ). To create cell free extract, a portion of cells was homogenised at 30,000 psi and then centrifuged at $7000 \mathrm{rpm}$ and $4{ }^{\circ} \mathrm{C}$ for $30 \mathrm{~min}$; the resulting supernatant was diluted 1:1 with the buffer described above.

\section{Chemical permeabilisation}

Acetone $(5 \% \mathrm{v} / \mathrm{v})$ was added to a portion of high cell density culture, which were then vortexed for $3 \mathrm{~min}$ and centrifuged at $7000 \mathrm{rpm}$ and $4{ }^{\circ} \mathrm{C}$ for $10 \mathrm{~min}$. The cell pellet was washed with phosphate buffer, centrifuged again and re-suspended in the same buffer before being diluted as with whole cells.

A portion of high cell density culture was diluted as with whole cells, except that the buffer also contained polymyxin B (final concentration $30 \mu \mathrm{M}$ ).

A portion of high cell density culture was diluted as with whole cells, except that the buffer also contained Triton X-100 (final concentration $0.25 \% \mathrm{v} / \mathrm{v}$ ).

\section{Biotransformation}

Biotransformations were carried out in $40 \mathrm{~mL}$ capped amber vials at $20^{\circ} \mathrm{C}$ and $200 \mathrm{rpm}$. The total reaction volume per vial was $1.3-1.45 \mathrm{~mL}$ with $0.2 \mathrm{~mL}$ n-octane per $1 \mathrm{~mL}$ aqueous phase. Low cell density cultures also contained $0.1 \mathrm{~mL}$ BEHP per $1 \mathrm{~mL}$ aqueous phase. At each time point, two vials were sacrificed for sampling. Wherever practicable, vials and samples were kept on ice after being removed from the incubator.

\section{Analytical methods \\ Quantification of CYP153A6}

Determination of active P450 concentration was based on the spectrophotometric assay described by Guengerich et al. [35], modified for the microliter scale. From each vial, $200 \mu \mathrm{L}$ of aqueous phase was drawn off, diluted 1:1 with $200 \mathrm{mM}$ potassium phosphate buffer $(\mathrm{pH}$ 8) containing $200 \mathrm{mM}$ glycerol, mixed with a few grains of sodium dithionite $\left(\mathrm{Na}_{2} \mathrm{~S}_{2} \mathrm{O}_{4}\right)$, and split equally between two wells of a flat-bottomed, clear, 96-well clip-in spectrophotometry plate (Greiner). One well was then exposed to carbon monoxide for 5-10 min via incubation in a closed container continuously flushed with $\mathrm{CO}$ (sample), while the other well was kept on the workbench (blank). A spectrophotometer (Spectramax M2, molecular devices in the case of high cell density experiments) was used to measure the absorbance of each well between 360 and $500 \mathrm{~nm}$ at $2 \mathrm{~nm}$ intervals. The blank well was used for baseline correction, after which the concentration of active CYP153A6 was calculated according to the following formula:

ActiveP450 $(\mu \mathrm{M})=\frac{(\text { absorbance at } 450 \mathrm{~nm})-(\text { absorbance at } 490 \mathrm{~nm})}{0.091} \times 2$ 


\section{Determination of glycerol dehydrogenase activity}

Determination of GLD activity was adapted from the method of Lin and Magasanik [36]. The assay solution consisted of $0.1 \mathrm{M}$ carbonate, $0.1 \mathrm{M}$ glycerol, $1 \mathrm{mM}$ $\mathrm{NAD}^{+}$and $33 \mathrm{mM}$ ammonium sulphate, at a final $\mathrm{pH}$ of 10.0-10.5. $2.9 \mathrm{~mL}$ of assay solution was mixed with $100 \mu \mathrm{L}$ of aqueous phase (appropriately diluted) and a spectrophotometer (Thermo Scientific Genesys $10 \mathrm{~S}$ UV-Vis) was used to measure the change in optical density at $340 \mathrm{~nm}$ over $3 \mathrm{~min}$, blanked against water. The GLD activity, in terms of $\mu$ moles $\mathrm{NAD}^{+}$reduced per minute per $\mathrm{mL}$, was calculated as follows:

$$
\begin{aligned}
& G L D \text { activity }(\mathrm{U} / \mathrm{min}) \\
& =\frac{\text { rate of change in } O D_{340 \mathrm{~nm}}}{6.22} \\
& \quad \times 30 \times(\text { dilution factor })
\end{aligned}
$$

\section{Extraction and analysis of organic phase}

The organic phase was extracted into $1 \mathrm{~mL}$ ethyl acetate containing $2 \mathrm{mM}$ decanol as an internal standard. Samples were analysed using via gas chromatography (Shimadzu GC-2010 in the case of high cell density experiments; Varian GC-3900 in the case of low cell density experiments) using a FactorFour VF-5 ms column (95\% dimethylpolysiloxane, $60 \mathrm{~m} \times 0.32 \mathrm{~mm}$ ). A significant unexpected peak was noticed in high cell density experiments, and was identified as octyl acetate via GC-MS of selected samples. The concentration of octyl acetate was calculated by comparing the areas of the 1-octanol and octyl acetate peaks.

The run programme on the Shimadzu was as follows: $1 \mu \mathrm{L}$ injection volume, split ratio of $50,2.4 \mathrm{~mL} \mathrm{~min}^{-1} \mathrm{H}_{2}$, oven temperature held at $60^{\circ} \mathrm{C}$ for $9 \mathrm{~min}$, ramped at $25^{\circ} \mathrm{C} \mathrm{min}^{-1}$ to $180^{\circ} \mathrm{C}$, held for $1.2 \mathrm{~min}$. The run programme on the Varian was as follows: $0.5 \mu \mathrm{L}$ injection volume, split ratio of 80 , $1 \mathrm{~mL} \mathrm{~min}{ }^{-1} \mathrm{~N}_{2}$, oven temperature held at $60^{\circ} \mathrm{C}$ for $3 \mathrm{~min}$, ramped at $30^{\circ} \mathrm{C} \mathrm{min}^{-1}$ to $180^{\circ} \mathrm{C}$, held for $7 \mathrm{~min}$.

\section{Additional files}

Additional file 1: Figure S1. Change in absorbance at $340 \mathrm{~nm}$ over the course of a three minute assay (corrected for dilution factors) giving an indication of rates of $\mathrm{NADH}$ regeneration. The above assays were performed on whole cell samples from low cell density resting cultures; cells were not in contact with octane at any point. The values displayed represent averages over two biological replicates, with multiple time points sampled per replicate.

Additional file 2: Figure S2. Biotransformations extended to $72 \mathrm{~h}$ for mechanically broken cells expressing additional GLD. Whole cells without additional GLD are included for comparison. Cultures were at a high cell density, and produced octyl acetate by-product alongside 1-octanol (an artefact of the expression system). The product concentrations shown here are the combined concentrations of 1-octanol and octyl acetate. Two vials were sacrificed to obtain each sample point. The organic phase was extracted into ethyl acetate and analysed via gas chromatography.
Additional file 3: Figure S3. Concentration of active P450 in various high cell density systems over $24 \mathrm{~h}$, determined via CO difference spectrophotometry in a microwell spectrophotometer. Two vials were sacrificed for sampling at each time point.

\section{Abbreviations}

Al: auto-induction (refers to growth/expression medium containing tryptone, yeast extract, glucose, glycerol and lactose); CAT: chloramphenicol acetyl transferase; CO: carbon monoxide; CYP: refers to strains containing pET28b+ with the operon encoding CYP153A6, FdR and Fdx; and an empty Duet vector (either pACYC or pCDF); CYP + GLD: refers to strains containing pET28b+ with the operon encoding CYP153A6, FdR and Fdx; and either pACYCDuet or pCDFDuet encoding GLD; Fdx: ferredoxin ("helper protein" associated with CYP153A6); FdR: ferredoxin reductase ("helper protein" associated with CYP153A6); GLD: glycerol dehydrogenase; NADH: nicotinamide adenine diphosphate (cellular cofactor utilised by CYP153A6); U: units of hydroxylation activity, in $\mu$ mol product formed per minute.

\section{Authors' contributions \\ BEW did the experimental design, carried out all experiments, and drafted the manuscript. MSS and CJF aided in the experimental design and in the data analysis. STLH conceived of the study and aided in the experimental design and data analysis. All authors participated in co-ordination and editing of the manuscript. All authors read and approved of the final manuscript.}

\section{Author details}

${ }^{1}$ Centre for Bioprocess Engineering Research (CeBER), Department of Chemical Engineering, University of Cape Town, Private Bag X3, Rondebosch, Cape Town 7701, South Africa. ${ }^{2}$ Department of Microbial, Biochemical and Food Biotechnology, University of the Free State, Bloemfontein, South Africa. ${ }^{3}$ South African DST-NRF Centre of Excellence in Catalysis, $C^{*}$ change, University of Cape Town, Private Bag, Rondebosch, Cape Town 7701, South Africa.

\section{Acknowledgements}

The authors gratefully acknowledge technical assistance from members of the Department of Microbial, Biochemical and Food Biotechnology at the University of the Free State in carrying out the experiments. Special thanks to Dirk Opperman from the Department of Microbial, Biochemical and Food Biotechnology for construction of plasmids and Suzana Savvi from CeBER for transformation of constructs to create $\mathrm{pET} 28 \mathrm{~b}+/ \mathrm{pACYCDuet}$ strains; and to Mariette Smart from CeBER for assistance in creating pET28b+/pCDFDuet strains.

\section{Competing interests}

The authors declare that they have no competing interests.

\section{Availability of data and materials}

The datasets generated and analysed during the current study are available from the corresponding author on reasonable request.

\section{Consent for publication}

Not applicable.

Ethics of approval and consent to participate

Not applicable.

\section{Funding}

Financial support from the University of Cape Town, the South African National Research Foundation and the South African Department of Science and Technology through the national Centre of Excellence in Catalysis ( $c^{*}$ change) and the SARChl Chair in Bioprocess Engineering is gratefully acknowledged.

\section{Publisher's Note}

Springer Nature remains neutral with regard to jurisdictional claims in published maps and institutional affiliations. 
Received: 28 January 2017 Accepted: 7 September 2017 Published online: 20 September 2017

\section{References}

1. Bergman RG. Organometallic chemistry: C-H activation. Nature. 2007;446:391-3.

2. Bordeaux M, Galarneau A, Drone J. Catalytic, mild, and selective oxyfunctionalization of linear alkanes: current challenges. Angew Chem. 2012;51:10712-23.

3. Bühler B, Schmid A. Process implementation aspects for biocatalytic hydrocarbon oxyfunctionalization. J Biotechnol. 2004;113:183-210.

4. Van Beilen JB, Funhoff EG. Expanding the alkane oxygenase toolbox: new enzymes and applications. Curr Opin Biotechnol. 2005;16:308-14.

5. Van Beilen JB, Funhoff EG. Alkane hydroxylases involved in microbial alkane degradation. Appl Microbiol Biotechnol. 2007;74:13-21.

6. Bernhardt R. Cytochromes P450 as versatile biocatalysts. J Biotechnol. 2006;124:128-45

7. Funhoff EG, Van Beilen JB. Alkane activation by P450 oxygenases. Biocatal Biotransformation. 2007;25:186-93.

8. Bernhardt R, Urlacher VB. Cytochromes P450 as promising catalysts for biotechnological application: chances and limitations. Appl Microbiol Biotechnol. 2014:98:6185-203.

9. Julsing MK, Cornelissen S, Bühler B, Schmid A. Heme-iron oxygenases: powerful industrial biocatalysts? Curr Opin Chem Biol. 2008;12:177-86.

10. Olaofe OA, Fenner CJ, Gudiminchi RK, Smit MS, Harrison STL. The influence of microbial physiology on biocatalyst activity and efficiency in the terminal hydroxylation of n-octane using Escherichia coli expressing the alkane hydroxylase, CYP153A6. Microb Cell Fact. 2013;12:8.

11. Hollmann F, Hofstetter $K$, Schmid A. Non-enzymatic regeneration of nicotinamide and flavin cofactors for monooxygenase catalysis. Trends Biotechnol. 2006:24:163-71.

12. Mouri T, Michizoe J, Ichinose H, Kamiya N, Goto M. A recombinant Escherichia coli whole cell biocatalyst harboring a cytochrome P450cam monooxygenase system coupled with enzymatic cofactor regeneration. Appl Microbiol Biotechnol. 2006;72:514-20.

13. Schewe H, Kaup B-A, Schrader J. Improvement of P450BM-3 whole-cell biocatalysis by integrating heterologous cofactor regeneration combining glucose facilitator and dehydrogenase in E. coli. Appl Microbiol Biotechnol. 2008;78:55-65.

14. Kataoka M, Yamamoto K, Kawabata H, Wada M, Kita K, Yanase H, Shimizu S. Stereoselective reduction of ethyl 4-chloro-3-oxobutanoate by Escherichia coli transformant cells coexpressing the aldehyde reductase and glucose dehydrogenase genes. Appl Microbiol Biotechnol. 1999;51:486-90.

15. Glick BR. Metabolic load and heterologous gene expression. Biotechnol Adv. 1995;13:247-61.

16. Rozkov A, Avignone-Rossa CA, Ertl PF, Jones P, O'Kennedy RD, Smith Jנ, Dale JW, Bushell ME. Characterization of the metabolic burden on Escherichia coli DH1 cells imposed by the presence of a plasmid containing a gene therapy sequence. Biotechnol Bioeng. 2004;88:909-15.

17. Grant C, Woodley JM, Baganz F. Whole-cell bio-oxidation of n-dodecane using the alkane hydroxylase system of P. putida GPol expressed in E. coli. Enzyme Microb Technol. 2011;48:480-6.

18. Julsing MK, Schrewe M, Cornelissen S, Hermann I, Schmid A, Bühler B. Outer membrane protein AlkL boosts biocatalytic oxyfunctionalization of hydrophobic substrates in Escherichia coli. Appl Environ Microbiol. 2012;78:5724-33.

19. Grant C, da Silva Damas Pinto AC, Lui H, Woodley JM, Baganz F. Tools for characterizing the whole-cell bio-oxidation of alkanes at microscale. Biotechnol Bioeng. 2012;109:2179-89.

20. Ni Y, Chen RR. Lipoprotein mutation accelerates substrate permeabilitylimited toluene dioxygenase-catalyzed reaction. Biotechnol Prog. 2005:21:799-805.

21. Cornelissen S, Julsing MK, Volmer J, Riechert O, Schmid A, Bühler B. Whole-cell-based CYP153A6-catalyzed (S)-limonene hydroxylation efficiency depends on host background and profits from monoterpene uptake via AlkL. Biotechnol Bioeng. 2013;110:1282-92.
22. Grant C, Deszcz D, Wei Y-C, Martínez-Torres RJ, Morris P, Folliard T, Sreenivasan R, Ward J, Dalby P, Woodley JM, Baganz F. Identification and use of an alkane transporter plug-in for applications in biocatalysis and whole-cell biosensing of alkanes. Sci Rep. 2014;4:5844.

23. Ruff AJ, Arlt M, van Ohlen M, Kardashliev T, Konarzycka-Bessler M, Bocola M, Dennig A, Urlacher VB, Schwaneberg U. An engineered outer membrane pore enables an efficient oxygenation of aromatics and terpenes. J Mol Catal B Enzym. 2016;134:285-294

24. Alonso-Gutierrez J, Chan R, Batth TS, Adams PD, Keasling JD, Petzold CJ, Soon Lee T. Metabolic engineering of Escherichia coli for limonene and perillyl alcohol production. Metab Eng. 2013:19:33-41.

25. Janocha S, Bernhardt R. Design and characterization of an efficient CYP105A1-based whole-cell biocatalyst for the conversion of resin acid diterpenoids in permeabilized Escherichia coli. Appl Microbiol Biotechnol. 2013;97:7639-49.

26. Meunier B, de Visser SP, Shaik S. Mechanism of oxidation reactions catalyzed by cytochrome P450 enzymes. Chem Rev. 2004;104:3947-80.

27. Schrewe M, Julsing MK, Bühler B, Schmid A. Whole-cell biocatalysis for selective and productive C-O functional group introduction and modification. Chem Soc Rev. 2013;42:6346-77.

28. Call TP, Akhtar MK, Baganz F, Grant C. Modulating the import of mediumchain alkanes in E. coli through tuned expression of FadL. J Biol Eng. 2016;10:5.

29. Scheps D, Honda Malca S, Richter SM, Marisch K, Nestl BM, Hauer B. Synthesis of $\omega$-hydroxy dodecanoic acid based on an engineered CYP153A fusion construct. Microb Biotechnol. 2013;6:694-707.

30. Favre-Bulle $\mathrm{O}$, Schouten T, Kingma J, Witholt B. Bioconversion of n-octane to octanoic acid by a recombinant Escherichia coli cultured in a two-liquid phase bioreactor. Biotechnology. 1991;9:367-371.

31. Posokhov YO, Kyrychenko A. Effect of acetone accumulation on structure and dynamics of lipid membranes studied by molecular dynamics simulations. Comp Biol Chem. 2013;46:23-31.

32. Lounatmaa K, Nanninga N. Effect of polymyxin on the outer membrane of Salmonella typhimurium: freeze-fracture studies. J Bacteriol. 1976;128:665-67.

33. Canovas $M$, Torroglosa T, Iborra JL. Permeabilization of Escherichia coli cells in the biotransformation of trimethylammonium compounds into L-carnitine. Enzyme Microb Technol. 2005;37:300-308.

34. Bordeaux M, de Girval D, Rullaud R, Subileau M, Dubreucq E, Drone J. High-celldensity cultivation of recombinant Escherichia coli, purification and characterization of a self-sufficient biosynthetic octane w-hydroxylase. Appl Microbiol Biotechnol. 2014;98:6275-83.

35. Guengerich FP, Martin MV, Sohl CD, Cheng Q. Measurement of cytochrome $\mathrm{P} 450$ and NADPH-cytochrome P450 reductase. Nat Protoc. 2009:4:1245-51.

36. Lin ECC, Magasanik B. The activation of glycerol dehydrogenase from Aerobacter aerogenes by monovalent cations. J Biol Chem. 1960;235:1820-23.

\section{Submit your next manuscript to BioMed Central and we will help you at every step:}

- We accept pre-submission inquiries

- Our selector tool helps you to find the most relevant journal

- We provide round the clock customer support

- Convenient online submission

- Thorough peer review

- Inclusion in PubMed and all major indexing services

- Maximum visibility for your research

Submit your manuscript at www.biomedcentral.com/submit 